\title{
Pengaruh Variabel Kinerja Keuangan Terhadap Devidend Payout Ratio (DPR) Pada Perusahaan Tambang Yang Go Publik di Bursa Efek Indonesia
}

\author{
Nuuridha Matiin \\ Jurusan Keuangan Perbankan \\ Politeknik Negeri Balikpapan \\ J1. Soekarno Hatta, Km. 8 \\ email : nurida_tjd@yahoo.com
}

\begin{abstract}
Abstrak
Penelitian ini tujuan dilakukan penelitian ini adalah untuk mengetahui kinerja keuangan yang dihasilkan oleh kelompok perusahaan pertambangan melalui tingkat rasio pembayaran deviden kas terhadap pemegang saham atau investor pada perusahaan tambang yang go public di Bursa Efek Indonesia.. Hasil analisis penelitian ini menyimpulkan bahwa variabel bebas yang berupa terbukti Current Ratio(CR), Debt to Equity Ratio (DER), Net Profit Margin (NPM), Return On Investment (ROI), dan Return On Equity (ROE). berpengaruh secara simultan dan signifikan terhadap Devidend Payout Ratio (DPR). Secara parsial, variabe Debt to Equity Ratio (DER) adalah variabel yang berpengaruh dominan dan signifikan terhadap Devidend Payout Ratio (DPR) pada perusahaan tambang yang go public di Bursa Efek Indonesia (BEI).
\end{abstract}

Kata kunci: Current Ratio (CR), Debt to Equity Ratio (DER), Net Profit Margin (NPM), Return On Investment (ROI), dan Return On Equity (ROE).

\begin{abstract}
The purpose of this study was conducted to determine the financial performance generated by the mining company's ratio of government through the payment of cash dividends to shareholders or investors in the mining thatwent public on the Indonesia Stock Exchange. The research was done by taking the population of the 10 mining that make periodic dividend payments to shareholders or investors. The analysis of this study concluded that the independent variables in the form of Current Ratio(CR), Debt to Equity Ratio (DER), Net Profit Margin (NPM), Return On Investment (ROI), and Return On Equity (ROE). also proved to be simultaneously and significant impact on Devidend Payout Ratio (DPR). Partially, the variable Debt to Equity Ratio (DER) is a variable that affects the dominant and significant impact on Devidend Payout Ratio (DPR) on the banks that went public on the Indonesia Stock Exchange (BEI).
\end{abstract}

Keywords : Current Ratio(CR), Debt to Equity Ratio(DER), Net Profit Margin (NPM), Return On Investment (ROI), dan Return On Equity (ROE).

\section{PENDAHULUAN}

Kinerja Keuangan perusahaan, adalah hal yang sangat penting terutamanya bagi pemilik perusahaan yaitu pemegang saham, karena modal yang ditanamkan berupa uang yang diinvestasikannya diharapkan dapat memberikan imbal hasil yang sepadan secara berkesinambungan. Kepada kinerjaperusahaan yang baik pemilik modal manaruh kepercayaannya. Karenanya tugas utama manajemen atau para manajer pada intinya adalah meningkatkan nilai (value) bagi para pemegang saham. Semakin meningkat nilai bagi pemegang saham menjadi penting pula bagi para manajer sendiri 
karena dapat memberikan nilai positif bagi kompensasi maupun kariernya sehingga akan meningkatkan motivasi baginya untuk senantiasa dapat membuat keputusan yang berdampak kepada penciptaan nilai.

\section{Tinjauan Pustaka}

\section{Manajemen Keuangan}

Pengertian manajemen menurut Hasibuan (2007:2), adalah ilmu dan seni mengatur proses pemanfaatan sumber daya manusia dan sumber-sumber lainnya secara efektif dan efisien untuk mencapai suatu tujuan tertentu.

\section{Analisis Laporan Keuangan}

Sedangkan definisi dari analisis laporan keuangan menurut Harahap (2007:190) dapat didefinisikan sebagai penguraian pos-pos laporan keuangan menjadi unit informasi yang lebih kecil dan melihat hubungannya yang bersifat signifikan atau yang mempunyai makna antara satu dengan yang lain baik antara data kuantitatif maupun data non kuantitatif dengan tujuan untuk mengetahui kondisi keuangan lebih dalam yang sangat penting dalam proses menghasilkan keputusan yang tepat.

\section{Analisis Rasio Keuangan}

Analisis rasio keuangan, yang menghubungkan unsur-unsur neraca dan perhitungan laba rugi satu dengan lainnya, dapat memberikan gambaran tentang sejarah perusahaan dan penilaian posisinya pada saat ini.

\section{Dividend Payout Ratio (DPR)}

Menurut Rahardjo (2005:69)

Semakin tinggi dividend payout ratio yang ditetapkan oleh suatu perusahaan, makin kecil dana yang tersedia untuk diinvestasikan di dalam perusahaan sehingga akan menghambat pertumbuhan perusahaan dan akan berdampak pada nilai suatu perusahaan.

\section{Current Ratio (CR)}

Menurut Horne dan Wachowicz (2005). Merupakan rasio likuiditas (liquidity ratio) menggambarkan kemampuan perusahaan dalam memenuhi kewajiban jangka pendeknya yang telah jatuh tempo.

\section{Debt to Equity Ratio (DER)}

Menurut Syamsuddin (2007:54) Debt to Equity Ratio (DER) adalah perbandingan atau rasio antara hutang terhadap ekuitas atau modal. Rasio ini menggambarkan perbandingan hutang dan ekuitas dalam pendanaan perusahaan dan menunjukkan kemampuan modal sendiri perusahaan tersebut untuk memenuhi seluruh kewajibannya

\section{Net Profit Margin (NPM)}

Menurut Syamsuddin (2007:62) Net profit margin adalah merupakan selisih dari keuntungan bersih atau selisih dari pada seluruh pendapatan atau penghasilan yang setelah dikurangkan dengan beban operasional dan administrasi serta beban pajak yang harus dibayar.

\section{Return On Investment (ROI)}

Menurut Horne dan Wachowicz (2005 : 34) menyatakan return on investment (ROI) dapat memberitahukan tingkat laba dari perusahaan yang berhubungan dengan investasi.

\section{Return On Equity (ROE)}

Menurut Syamsuddin (2007:54), ROE adalah perbandingan antara jumlah laba bagi pemilik modal sendiri di satu pihak dengan jumlah modal sendiri yang menghasilkan laba tersebut di lain pihak. Dengan kata lain rentabilitas modal sendiri adalah kemampuan suatu perusahaan dengan modal sendiri yang bekerja di dalamnya untuk menghasilkan keuntungan.

\section{Hipotesis}

1. Diduga bahwa variabel Current Ratio, Debt to Equity Ratio (DER), Net Profit Margin (NPM), Return On Investment (ROI) dan Return On Equity (ROE) berpengaruh secara bersama-sama (simultan) terhadap Dividend Payout Ratio 
(DPR) pada perusahaan tambang yang go publik di Bursa Efek Indonesia.

2. Diduga variabel Current Ratio (CR) yang berpengaruh dominan terhadap Payout Ratio (DPR) pada perusahaan tambang yang go publik di Bursa Efek Indonesia.

\section{METODE PENELITIAN}

\section{Rancangan Penelitian}

Dalam penelitian ini digunakan jenis data kuantitatif berupa data sekunder yang diperoleh dengan mengakses website www.idx.co.id dan menggunakan Indonesian Capital Market Directory (ICMD). Berdasarkan hipotesis penelitian yang diajukan diidentifikasi 5 variabel yang digunakan dalam penelitian ini yaitu Current Ratio (CR), Debt to Equity (DER), Net Profit Margin (NPM), Return On Investment (ROI), Return On Equity (ROE) menjadi variabel independen, sedangkan Dividend Payout Ratio (DPR) menjadi variabel dependen.

\section{Definisi Operasional}

Untuk memberikan penjelasan mengenai indikator yang digunakan dalam penelitian dan usaha pemecahan masalah sesuai dengan judul penelitian ini, maka dirumuskan mengenai definisi operasional yang dapat dijabarkan sebagai berikut:

1) Variabel Dependen : $Y=$ Dividend Payout Ratio (DPR)

2) Variabel Independen yang terdiri dari :

a. X1= Current Ratio (CR)

b. $\mathrm{X} 2=$ Debt to Equity (DER)

c. $\mathrm{X} 3=$ Net Profit Margin (NPM)

d. $\mathrm{X} 4=$ Return On Investment (ROI)

e. X5= Return On Equity (ROE)

\section{Jangkauan Penelitian}

Penelitian ini berlokasi di Indonesia, khususnya pada perusahaan tambang yang go public terdaftar di Bursa Efek Indonesia (BEI) yang diperoleh datanya dari Indonesian Capital Market Directoy (ICMD). Waktu penelitian diestimasi dilakukan pada bulan Mei - Juli 2013.

\section{Populasi dan Sampel}

Populasi yang digunakan dalam penelitian ini adalah seluruh perusahaan tambang yang go public terdaftar di Bursa Efek Indonesia (BEI), yang diperoleh datanya dari Indonesian Capital Market Directory (ICMD

\section{Sumber Data}

Data dalam penelitian ini adalah berupa data sekunder dari laporan keuangan tahunan perusahaan. Pengumpulan data menggunakan teknik dokumentasi yang diperoleh dari data base Bursa Efek Indonesia .

\section{Instrumen Penelitian}

Berkaitan dengan data yang digunakan adalah data sekunder, maka tidak diperlukan pembuatan instrumen penelitian seperti pada data primer.

\section{Teknik Pengumpulan Data}

Data dalam penelitian ini adalah berupa data sekunder dari laporan keuangan tahunan perusahaan.

\section{a. Pengujian Hipotesis}

Untuk membuktikan hipoteisis apakah benar atau tidak maka dilakukan pengujian hipoteisis yang dilakukan dengan sebagai berikut:

1. Uji Koefisien Korelasi (R)

2. Uji Koefisien Determinasi $\left(\mathrm{R}^{2}\right)$

3. Uji F (simultan)

4. Uji t (parsial)

b. Uji Asumsi Klasik

1. Uji Normalitas

2. Uji Autokolerasi

3. Uji Multikolinearitas

4. Uji Heteroskedastisitas 


\section{Analisis dan Pembahasan}

\section{Analisis Deskriptif}

Berdasarkan hasil dari analisis dengan menggunakan program SPSS versi 17 dapat dilihat analisis deskriptif sebagai berikut :

Tabel 5.2. Statistik Deskriptif

\begin{tabular}{|l|r|r|r|}
\hline & Mean & Std. Deviation & \multicolumn{1}{|c|}{$\mathrm{N}$} \\
\hline Devidend Payout & .1441 & .10826 & 56 \\
Curent Rasio & 2.9079 & 1.68869 & 56 \\
Debt To Equity & 1.0038 & .89967 & 56 \\
Net Profit Margin & 35.0295 & 16.43174 & 56 \\
ROI & 9.5700 & 8.79602 & 56 \\
& & & 56 \\
\hline
\end{tabular}

Sumber: Output SPSS versi 17

Pada tabel 5.2. di atas secara deskriptif menunjukkan bahwa Devidend Payout Rasio (DPR) perusahaan tambang yang go publik di BEI pada tahun 2005 sampai dengan 2011 rata-rata sebesar $14,41 \%$ dengan standar deviasi sebesar $10,82 \%$ artinya, nilai terkecil dari Devidend Payout Ratio (DPR) rata-rata sebesar 3,59\% (14,41\%-10,82\%) sedangkan nilai terbesar dari Devidend Payout Ratio (DPR) rata-rata sebesar 25,83\% (14,41\% $10,82 \%)$.

\subsection{Pengujian Asumsi Klasik}

1. Uji Normalitas

Tabel 5.4 Hasil Uji Normalitas

\begin{tabular}{|ll|r|}
\hline & & \multicolumn{1}{|c|}{$\begin{array}{c}\text { Standardized } \\
\text { Residual }\end{array}$} \\
\hline $\mathrm{N}$ & & 56 \\
Normal & Mean & .0000000 \\
Parameters & Std. Deviation & .95346259 \\
Most Extreme & Absolute & .141 \\
Differences & & \\
& Positive & .141 \\
& Negative & -.084 \\
Kolmogorov-Smirnov Z & 1.057 \\
Asymp. Sig. (2-tailed) & .214 \\
\hline
\end{tabular}

Sumber: Output SPSS versi 17.

Hasil uji normalitas seperti tersaji di atas menunjukkan bahwa data penelitian telah teredistribusi normal yang dibuktikan dengan asymp sig. sebesar 0,214 yang lebih besar dari tingkat signifikansi penelitian 5\%. Oleh karena data penelitian telah terdistribusi normal, maka data dapat digunakan dalam pengujian dengan model regresi berganda.

\section{Pengujian Autokorelasi} Tabel 5.5. Pengambilan Keputusan Uji Durbin Watson

\begin{tabular}{|l|l|l|}
\hline \multicolumn{1}{|c|}{ Hipotesis Nol } & \multicolumn{1}{|c|}{ Keputusan } & \multicolumn{1}{c|}{ Jika } \\
\hline $\begin{array}{l}\text { Tidak ada } \\
\text { Autokorelasi positif } \\
\text { Tidak ada }\end{array}$ & Tolak & $0 \leq \mathrm{d} \leq \mathrm{dl}$ \\
$\begin{array}{l}\text { Autokorelasi posistif } \\
\text { Tidak ada }\end{array}$ & No decision & $\mathrm{dl} \leq \mathrm{d} \leq \mathrm{du}$ \\
$\begin{array}{l}\text { Autokorelasi negatif } \\
\text { Tidak ada }\end{array}$ & Tolak & $4-\mathrm{dl}<\mathrm{d}<4$ \\
$\begin{array}{l}\text { Autokorelasi negatif } \\
\text { Tidak ada } \\
\text { Autokorelasi positif } \\
\text { atau negatif }\end{array}$ & Tidak Ditolak & $\mathrm{du}<\mathrm{d}<4-\mathrm{du}$ \\
& & \\
\hline
\end{tabular}

Sumber : Ghozali, 2011 
Pada tabel 5.6. menunjukkan nilai Durbin Watson sebesar 1,145 dengan nilai $\mathrm{dl}=$ 1,018 dan $\mathrm{du}=1,837$, nilai $4-\mathrm{dl}=2,982$ dan nilai $4-\mathrm{du}=2,163$ jika melihat dari tabel keputusan di atas dibantu dengan tabel Durbin Watson dengan jumlah variabel independen sebanyak 4 maka keputusannya adalah tidak ditolak (du $<$ d $<4$-du) karena tidak ada korelasi positif dan negatif di dalam model artinya tidak terdapat autokorelasi.

\section{Pengujian Multikolinearitas}

Adapun pengujian secara manual adanya multikolinearitas terhadap model adalah sebagai berikut:

\section{Tabel 5.6. Pengujian Multikolinearitas}

\begin{tabular}{|l|l|l|l|}
\hline Simbol & Variabel Dependen & VIF & Keterangan \\
\hline $\mathrm{X}_{1}$ & Curent Ratio & 1,64 & Lebih kecil dari 10 \\
\hline $\mathrm{X}_{2}$ & Debt To Equity & 1,52 & Lebih kecil dari 10 \\
\hline $\mathrm{X}_{3}$ & Net Profit Margin & 1,24 & Lebih kecil dari 10 \\
\hline $\mathrm{X}_{4}$ & ROI & 2,24 & Lebih kecil dari 10 \\
\hline $\mathrm{X}_{5}$ & ROE & 1,72 & Lebih kecil dari 10 \\
\hline
\end{tabular}

Sumber: Lampiran 1, diolah

Hasil pengujian berdasarkan tabel 5.6 menunjukkan dari lima variabel independen memiliki nilai VIF lebih kecil

\section{Pengujian Heteroskedastisitas}

Park, mengemukakan metode bahwa variance $\left(\mathrm{s}^{2}\right)$ merupakan fungsi dari

Tabel 5.7. Uji Park Heteroskedastisitas

\begin{tabular}{|c|c|c|c|c|c|c|}
\hline \multirow{2}{*}{\multicolumn{2}{|c|}{ Model }} & \multicolumn{2}{|c|}{ Unstandardized Coefficients } & \multirow{2}{*}{$\begin{array}{c}\text { Standardized } \\
\text { Coefficients }\end{array}$} & \multirow[b]{2}{*}{$\mathrm{t}$} & \multirow[b]{2}{*}{ Sig. } \\
\hline & & $\mathrm{B}$ & Std. Error & & & \\
\hline \multirow[t]{6}{*}{1} & (Constant) & .052 & .019 & & 2.692 & .010 \\
\hline & Curent Rasio & .000 & .004 & -.018 & -.108 & .914 \\
\hline & Debt To Equity & .013 & .007 & .303 & 1.922 & .060 \\
\hline & Net Profit Margin & .000 & .000 & -.343 & -1.320 & .202 \\
\hline & ROI & .000 & .001 & .097 & .507 & .614 \\
\hline & ROE & .001 & .000 & .234 & 1.390 & .171 \\
\hline
\end{tabular}

Sumber : Output SPSS versi 17

dari 10 ini menunjukkan bahwa tidak terdapat multikolinearitas,

variabel-variabel independen yang dinyatakan dalam tabel berikut: 
Seperti terlihat pada tabel 5.7. di atas dengan melakukan regresi terhadap nilai log Ui2 yang diperoleh melalui hasil unstandardized yang dikuadratkan dan di log-kan dari hasil signifikan menunjukkan tidak ada variabel independen yang signifikan atau lebih kecil dari 5\%. Hal ini menunjukkan bahwa tidak terdapat heteroskedastisitas di dalam model.

Tabel 5.9. Koefisien determinan

\begin{tabular}{|r|r|r|r|r|r|}
\hline Model & R & R Square & \multicolumn{1}{|c|}{$\begin{array}{c}\text { Adjusted R } \\
\text { Square }\end{array}$} & $\begin{array}{l}\text { Std. Error of the } \\
\text { Estimate }\end{array}$ & Durbin-Watson \\
\hline 1 & $.802^{\mathrm{a}}$ & .643 & .607 & .06785 & 1.145 \\
\hline
\end{tabular}

\section{Sumber : Output SPSS versi 17}

Koefisien determinan $\left(\mathrm{R}^{2}\right)=0,643$ berarti variasi variabel bebas Current Ratio (CR) Debt to Equity Ratio (DER), Net Profit Margin (NPM), Return On Investment (ROI), Return On Equity
(ROE) menjelaskan variasi variabel terikat (Devidend Payout Ratio) sebesar 64,3\% sedangkan $35,7 \%$ dijelaskan oleh variabel yang lain.

Tabel 5.10. Hasil Uji Signifikansi -F

\begin{tabular}{|ll|r|r|r|r|r|}
\hline Model & & Sum of Squares & df & Mean Square & F & \multicolumn{1}{c|}{ Sig. } \\
\hline 1 & Regression & .414 & 5 & .083 & 18.000 & $.000^{\mathrm{a}}$ \\
& Residual & .230 & 50 & .005 & & \\
& Total & .645 & 55 & & & \\
& & & & & \\
\hline
\end{tabular}

Sumber: Output SPSS versi 17

Dalam penelitian ini, variabel bebas secara simultan/ bersama-sama dengan menggunakan uji $\mathrm{F}$ berpengaruh secara signifikan terhadap Devidend Payout Ratio di perusahaan tambang yang go publik di BEI seperti terlihat pada tabel 5.9. dengan nilai $F_{\text {hitung }}$ sebesar 18,000 dan tingkat signifikansi $0,000 \quad(0,0 \%)$ atau lebih kecil dari $\alpha=5 \%$.

\subsection{Pengujian Statistik} Tabel 5.11 Koefisien Regresi

\begin{tabular}{|c|c|c|c|c|c|c|c|c|}
\hline \multirow{2}{*}{\multicolumn{2}{|c|}{ Model }} & \multicolumn{2}{|c|}{$\begin{array}{l}\text { Unstandardized } \\
\text { Coefficients }\end{array}$} & \multirow{2}{*}{$\begin{array}{c}\text { Standardized } \\
\text { Coefficients }\end{array}$} & \multirow[b]{2}{*}{$\mathrm{t}$} & \multirow[b]{2}{*}{ Sig. } & \multicolumn{2}{|c|}{ Collinearity Statistics } \\
\hline & & B & Std. Error & & & & Tolerance & VIF \\
\hline \multirow[t]{6}{*}{1} & (Constant) & -.005 & .035 & & -.153 & .879 & & \\
\hline & Curent Rasio & .019 & .007 & .301 & 2.782 & .008 & .609 & 1.642 \\
\hline & Debt To Equity & .028 & .013 & .235 & 2.258 & .028 & .659 & 1.517 \\
\hline & Net Profit Margin & -.001 & .001 & -.180 & -1.910 & .062 & .803 & 1.246 \\
\hline & ROI & .006 & .002 & .447 & 3.526 & .001 & .445 & 2.249 \\
\hline & ROE & .003 & .001 & .382 & 3.440 & .001 & .580 & 1.725 \\
\hline
\end{tabular}


Dari data di atas diperoleh persamaan regresi sebagai berikut:

$$
\begin{aligned}
& \hat{Y}=-0,05+0,19\left(\mathrm{X}_{1}\right)+0,28\left(\mathrm{X}_{2}\right)-0,01\left(\mathrm{X}_{3}\right) \\
& +0,06\left(\mathrm{X}_{4}\right)+0,03\left(\mathrm{X}_{5}\right)+\mathrm{e}
\end{aligned}
$$

Dengan demikian dapat dikatakan bahwa setiap perubahan variabel bebas Current Ratio
(CR) Debt to Equity Ratio (DER), Net Profit Margin (NPM), Return On Investment (ROI), Return On Equity (ROE), akan mempengaruhi Dividend Payout Ratio (DPR) di perusahaan tambang yang go publik di Bursa Efek Indonesia yang dapat diuraikan sebagai berikut:

\section{A. Pengujian Hipotesis}

1. Hipotesis Pertama

Tabel 5.10 Analysis of Varians (ANOVA)

\begin{tabular}{|rl|r|r|r|r|r|}
\hline Model & & Sum of Squares & df & Mean Square & F & Sig. \\
\hline 1 & Regression & .414 & 5 & .083 & 18.000 & $.000^{\mathrm{a}}$ \\
& Residual & .230 & 50 & .005 & & \\
& Total & .645 & 55 & & & \\
\hline
\end{tabular}

Dalam penelitian ini, variabel Current Ratio (CR) Debt to Equity Ratio (DER), Net Profit Margin (NPM), Return On Investment (ROI), Return On Equity (ROE) secara simultan (bersama-sama) dengan menggunakan uji $\mathrm{F}$, mempunyai pengaruh signifikan terhadap Devidend
Payout Ratio di perusahaan tambang yang go publik di BEI seperti terlihat pada tabel 5.8 dengan nilai Fhitung sebesar 18.000 dan tingkat signifikansi 0,000 atau $0,000 \%$ lebih kecil dari 5\%. Sehingga dapat disimpulkan bahwa hipotesis pertama di terima.

\section{Hipotesis Kedua}

Tabel 5.12 Hasil Uji-t (t-test)

\begin{tabular}{|l|c|c|c|c|}
\hline \multicolumn{1}{|c|}{ Variabel } & t-hitung & $\begin{array}{c}\text { t-tabel } \\
(\mathbf{d f =} \mathbf{n - k})\end{array}$ & $\begin{array}{c}\text { sig.t } \\
(\boldsymbol{\alpha}=\mathbf{0 , 0 5})\end{array}$ & Kesimpulan \\
\hline Current Ratio (X1) & 2,782 & 1,673 & 0,008 & Signifikan \\
Debt to Equity Ratio (X2) & 2,258 & 1,673 & 0,028 & Signifikan \\
Net Profit Margin (X3) & 1,910 & 1,673 & 0,062 & Tidak Signifikan \\
Return On Investment(X4) & 3.526 & 1,673 & 0,001 & Signifikan \\
Return On Equity (X5) & 3.440 & 1,673 & 0,001 & Signifikan \\
\hline
\end{tabular}

Sumber : Lampiran 2

Dari hasil penelitian, nilai $t_{\text {hitung }}$ Debt to Equity Ratio (DER), sebesar $2,258 \%$ dengan tingkat signifikan sebesar 0,028 atau $2,8 \%$ lebih kecil dari $\alpha=5 \%$. berarti terdapat pengaruh secara signifikan antara Debt to Equity Ratio (DER) dengan Dividend Payout Ratio (DPR). Sehingga dapat disimpulkan bahwa hipotesis kedua ditolak 


\subsection{Pembahasan Hasil Penelitian}

Koefisien determinan $\left(\mathrm{R}^{2}\right)=0,643$ berarti variasi variabel bebas Current Ratio (CR) Debt to Equity Ratio (DER), Net Profit Margin (NPM), Return On Investment (ROI), Return On Equity (ROE) menjelaskan variasi variabel terikat (Devidend Payout Ratio) sebesar 64,3\% sedangkan $35,7 \%$ dijelaskan oleh variabel yang lain, hasil penelitian ini sejalan dengan teori dan penelitian terdahulu yang dilakukan oleh Martinus RH (2012).

1. Jika tidak ada Current Ratio (CR), Debt to Equity Ratio (DER), Net Profit Margin (NPM), Return On Investment (ROI), Return On Equity (ROE) maka Dividend Payout Ratio (DPR) rata-rata sebesar $0,05 \%$ per tahun.

2. Bila Current Ratio $\left(\mathrm{X}_{1}\right)$ bertambah sebesar 1\%,- maka Dividend Payout Ratio (DPR) meningkat sebesar $0,19 \%$ dengan asumsi $\mathrm{X}_{2}$, $\mathrm{X}_{3}$, dan $\mathrm{X}_{4}$ tetap. Nilai $\mathrm{t}_{\text {hitung }}$ sebesar 2,782 \% dengan tingkat signifikansi sebesar 0,008 atau 0,8 $\%$ lebih kecil dari nilai $\alpha=5 \%$, berarti terdapat pengaruh yang signifikan antara Current Ratio (CR) dengan Dividend Payout Ratio (DPR).

3. Bila Debt to Equity Ratio $\left(\mathrm{X}_{2}\right)$ bertambah sebesar 1\%,- maka Dividend Payout Ratio meningkat sebesar $0,028 \%$ dengan asumsi $\mathrm{X}_{1}$, $\mathrm{X}_{3}$, dan $\mathrm{X}_{4}$ tetap. Nilai $\mathrm{t}_{\text {hitung }}$ sebesar 2,258 \% dengan tingkat signifikansi sebesar 0,028 atau 2,8 $\%$ lebih kecil dari nilai $\alpha=5 \%$, berarti terdapat pengaruh yang signifikan antara Debt to Equity Ratio dengan Dividend Payout Ratio (DPR). Debt to Equity Ratio (DER) mencerminkan kemampuan perusahaan dalam memenuhi segala kewajibannya, yang ditunjukkan oleh berapa bagian modal sendiri yang digunakan untuk membayar hutang.
4. Bila Net Profit Margin $\left(\mathrm{X}_{3}\right)$ bertambah sebesar 1\%, maka Dividend Payout Ratio menurun sebesar - 0,01 \% dengan asumsi $\mathrm{X}_{1}, \mathrm{X}_{2}$, dan $\mathrm{X}_{4}$ tetap. Nilai $\mathrm{t}_{\text {hitung }}$ sebesar - 1,910 dengan tingkat signifikansi sebesar 0,062 atau 6,2 $\%$ lebih besar dari nilai $\alpha=5 \%$, berarti tidak terdapat pengaruh yang signifikan antara Net Profit Margin (NPM) dengan Dividend Payout Ratio (DPR).

5. Bila Return On Investment (x4) bertambah sebesar 1\%, maka Dividend Payout Ratio meningkat sebesar $0,06 \%$ dengan asumsi $\mathrm{x} 1$, ${ }_{\mathrm{X} 2}$, dan $\mathrm{x} 3$ tetap. Nilai thitung sebesar $3,526 \%$ dengan tingkat signifikansi sebesar 0,001 atau $1 \%$ lebih kecil dari nilai $\alpha=5 \%$ berarti terdapat pengaruh yang signifikan antara Return On Investment (ROI) dengan Dividend Payout Ratio (DPR).

6. Bila Return On Equity (x5) bertambah sebesar 1\%, maka Dividend Payout Ratio meningkat sebesar 0,03\% dengan asumsi $\mathrm{x} 1$, $\mathrm{X} 2, \mathrm{x} 3$ dan $\mathrm{x} 4$ tetap. Nilai thitung sebesar 3,440\% dengan tingkat signifikansi sebesar 0,001 atau $1 \%$ lebih kecil dari nilai $\alpha=5 \%$ berarti terdapat pengaruh yang signifikan antara Return On Equity (ROE) dengan Dividend Payout Ratio (DPR).

\section{Kesimpulan}

Berdasarkan hasil analisis dan pembahasan dari penelitian ini, maka dapat dikemukakan beberapa kesimpulan sebagai berikut:

1. Secara simultan atau bersama-sama variabel Current Ratio (CR) Debt to Equity Ratio (DER), Net Profit Margin (NPM), Return On Investment (ROI), Return On Equity (ROE) dengan menggunakan uji $\mathrm{F}$, mempunyai pengaruh signifikan terhadap Devidend Payout Ratio 
(DPR) di perusahaan tambang yang go publik di BEI seperti terlihat pada tabel 5.9 dengan nilai Fhitung sebesar 18.000 dan tingkat signifikansi 0,000 atau $0,000 \%$ lebih kecil dari $5 \%$. Sehingga dapat disimpulkan bahwa hipotesis pertama di terima.

2. Dari hasil penelitian dapat disimpulkan bahwa diantara kelima variabel Current Ratio (CR) Debt to Equity Ratio (DER), Net Profit Margin (NPM), Return On Investment (ROI), Return On Equity (ROE), maka variabel yang paling dominan berpengaruh signifikan terhadap kinerja perusahaan tambang yang go publik di BEI yang diukur dari Devidend Payout Ratio (DPR) adalah Dari hasil penelitian, nilai $t_{\text {hitung }}$ Debt To Equity (DER) sebesar 2,258\% dengan tingkat signifikan sebesar 0,028 atau $2,8 \%$ lebih kecil dari $\alpha=$ $5 \%$. berarti terdapat pengaruh secara signifikan antara Curent Ratio dengan Devidend Payout Ratio. Sehingga dapat disimpulkan bahwa hipotesis kedua ditolak.

\section{Daftar Pustaka}

Amarjit Gill, 2010. The Open Business Journal Determinants of Dividend Payout Ratios TUI University, CA 90630, USA

Anthony Flint, 2010. Journal of Business and Finance Research Predicting future earnings Growth : A Test Of the Dividend Payout Ratio In the Australian Market University of Wollongong

Brigham, E.F dan Houston, J.F, 2005. Manajemen Keuangan. Terjemahan Hermawan Wibosono, Erlangga, Jakarta.

Gujarati, Damodar. 2003. Ekonometrika Dasar. Edisi Enam. Jakarta : Erlangga.

Ghozali, Imam. 2005. Analisis Multivariat dengan Program SPSS. Edisi ke-3. Badan Penerbit UNDIP. Semarang.
G.R. Terry dan L .W. Rue. 2008. DasarDasar Manajemen, Jakarta: Bumi Akssara.

Hasibuan, N. 2007. Ekonomi Industri. : Persaingan, Monopoli dan Regulasi. LP3ES, Jakarta.

Harahap, Sofyan Syafri B. 2007. Teori Akuntansi. Cetakan Ketujuh.

Raja Grafindo Persada, Jakarta.

Husnan, Suad dan Enny Pudjiastuti. 2004. Dasar-Dasar Manajemen Keuangan. UPP STIM YKPN, Yogyakarta.

Intan Permatasari 2009 Dalam penelitiannya berjudul Analisis FaktorFaktor yang Mempengaruhi Dividend Payout Ratio Studi pada Perusahaan yang Listed di Bursa Efek Jakarta.

Kania dan Bacon 2005 Dalam penelitiannya berjudul pengaruh investasi, likuiditas, profitabilitas, pertumbuhan perusahaan terhadap kebijakan Dividend Payout Ratio pada Perusahaan yang Listed di Bursa Efek Jakarta.

Lisa Marlina dan Clara Danica 2009. Dalam penelitiannya berjudul Analisis Pengaruh Cash Position, Debt to Equity Ratio, dan Return On Asset terhadap Dividend Payout Ratio Studi pada Perusahaan yang Listed di Bursa Efek Jakarta..

Lewis.M.2007. Dasar-Dasar Manajemen Manajemen Keuangan. Bandung: Refika Aditama.

Nuriyanto.2007. Dalam penelitiannya berjudul Analisis Beberapa Variabel Yang Berpengaruh Terhadap Dividend Payout Ratio (DPR) Pada Perusahaan Manufaktur Yang Go Public Di Bursa Efek Jakarta.

Mat Juri. 2009. Dalam penelitian berjudul Analisis Variabel-Variabel Yang Mempengaruhi Return On Equity (ROE) Perusahaan Tambang Yang Go Publik Di Bursa Efek Indonesia. 
Martinus RH. 2012. Dalam penelitian berjudul Pengaruh Beberapa Variabel Kinerja Keuangan Terhadap Devidend Payout Ratio Pada Bank Yang Go Public Di Bursa Efek Indonesia.

Md. Reiazul Haque. 2013. Research Journals Relationship between Dividend Payout and Economic Value Added Technology University Bangladesh

Prihantoro. 2003 analisis faktor-faktor yang mempengaruhi Dividend Payout Ratio pada 148 perusahaan publik yang terdaftar di Bursa Efek Jakarta.

Rahardjo. 2005. Financial Mangement Prinsip-Prinsip Manajemen Keuangan. Buku 2, Edisi 12. Salemba Empat, Jakarta.

Sartono, R.Agus. 2003. Manajemen

Keuangan Teory Dan Aplikasi. Edisi Ketiga, BPFE Yogyakarta.

Sawir, Agnes.2005. Analisis Kinerja Keuangan dan Perencanaan Keuangan Perusahaan, Percetakan PT SUN, Jakarta.
Sunarto dan Kartika.2003. Analisis Faktorfaktor yang Mempengaruhi Dividen Kas di Bursa Efek Jakarta.

Sutriso.2001. Dalam penelitiannya berjudul "Analisis Faktor-faktor Yang Mempengaruhi Dividend Payout Ratio (DPR), pada Perusahaan Publik di Indonesia.

Sugiyono. 2008. Statistika Untuk Penelitian. Bandung: Alfabeta.

Soemarso, S.R . 2004. Akuntansi Suatu Pengantar. Rineka Cipta, Jakarta.

Syamsuddin, Lukman. 2004. Manajemen Keuangan Perusahaan. Raja Grafindo Persada, Jakarta.

Weston, J. Fred dan Thomas Copeland. 2005. Manajemen Keuangan. Edisi 